\title{
Hamsa
}

H闹MSA Journal of Judaic and Islamic Studies

$4 \mid 2018$

Varia

\section{Self-Abnegation among the children of Abraham: Judaism and Islam}

\section{Meir Wachs}

\section{Q OpenEdition \\ 1 Journals}

\section{Electronic version}

URL: https://journals.openedition.org/hamsa/592

DOI: 10.4000/hamsa.592

ISSN: 2183-2633

\section{Publisher}

CIDEHUS - Centro Interdisciplinar de História Culturas e Sociedades da Universidade de Évora

\section{Electronic reference}

Meir Wachs, "Self-Abnegation among the children of Abraham: Judaism and Islam", Hamsa [Online], 4 I 2018, Online since 31 March 2018, connection on 13 May 2021. URL: http://journals.openedition.org/ hamsa/592 ; DOl: https://doi.org/10.4000/hamsa.592

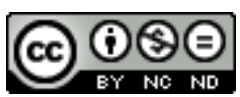

Hamsa est mise à disposition selon les termes de la Licence Creative Commons Attribution - Pas d'Utilisation Commerciale - Pas de Modification 4.0 International. 


\title{
Self-Abnegation among the children of Abraham: Judaism and Islam
}

\author{
Meir Wachs \\ University of Oxford \\ meir.wachs@bfriars.ox.ac.uk
}

\section{Resumo}

A palavra "abnegação", em português, como em inglês, advém do latim ab ("afastado") e negare ("negar"), refletindo a ideia de negação, rejeição ou renúncia. A abnegação de si mesmo pode englobar uma grande variedade de práticas e de ideias. Com o risco de uma excessiva simplificação, este trabalho tenta comparar duas vastas tradições sobre termos particularmente complexos - as ideias místicas de união e aniquilação. A linguagem e a terminologia diferem tanto nas tradições, quanto certamente em termos comparativos. No entanto, este artigo argumenta que, emanadas do judaísmo e do islamismo, surgem trajetórias extremamente semelhantes que devemos tentar entender.

Palavras-chave: Auto-Abnegação, Judaísmo, Islão, Misticismo

\begin{abstract}
:
The word abnegation in English comes from the Latin ab ("away") and negare ("deny"), connoting a denial, rejection or renunciation. Abnegation of the self can encompass a wide variety of practices and ideas. At the risk of egregious oversimplification, this paper attempts to compare two vast traditions in an arena of particular complexity - the mystical ideas of union and annihilation. Language and terminology differ both within the traditions and certainly in comparison. Nevertheless, this paper argues that arising from deep within both Judaism and Islam are remarkably similar trajectories which we shall endeavor to understand ${ }^{1}$.
\end{abstract}

Keywords: Self-Abnegation, Judaism, Islam, Mysticism

The Arabic noun of $f a n \bar{a}^{\prime}$ arises from the root $f-n$ - $^{\prime}$ and is derived from the word faniya, meaning to pass away or to be annihilated. Wehr also offers the mystical connotation of the "extinction of individual consciousness and obliteration of the ego/self"' root $b-q-$ ' and the word baqiya, meaning to remain or survive ${ }^{3}$. The emergence of these terms in Islam can be traced back to the Quranic verse "All that dwells upon thy earth is perishing... yet still

\footnotetext{
${ }^{1}$ This paper reviews and examines the ideas of abnegation within respective traditions and their trajectories, however it is important to note that it does not attempt to discuss overlap nor common origin or structure of the ideas themselves. Much work has and continues to be done in this area. Additionally, as we focus here on the abnegation of self in the arena of the mystical, the subject of the abnegation of the physical self or body will not be addressed.

${ }^{2}$ Hans Wehr and J. Milton Cowan, A Dictionary of Modern Written Arabic, Lavergne, TN., Snowball, 2016, p. 854.

${ }^{3}$ Possibly connoting Dār-al- Baqā', the immortal afterlife.
} 
abides the face of Allah..." ${ }^{4}$. While the verse can be said to simply demonstrate the transcendent nature of God and the transient nature of this world, it has nevertheless become seen as a model for mystical practice. The idea of the abnegation of self (and becoming a vessel of the divine) is also supported conceptually by the hadith qudsi: "When My servant draws near to Me through obligatory and free devotions... I become the hearing with which he sees, the hands with which he touches, the feet with which he walks..." ${ }^{5}$. The prophetic tradition of: "Die before you Die" (mūtū qabla an tamūtū), develops the idea still further ${ }^{6}$.

The emergence of the application of these concepts can be seen in their earliest elaborate expression in the works of Bāyazīd al-Bisțāmī (d. 874-879) ${ }^{7}$. Perhaps Abū Nașr al-Sarraj (d. 988) records his view most presciently:

"Once God raised me up and placed me before him and said to me: 'Adorn me with your unity and clothe me in your "I-ness" and raise me up unto your oneness, so that when creatures see me, they may say "We have seen you and you are that" yet I, al-Bistamī' will not be there at all'"'8.

Thus al-Bisțāmī describes the process of $f a n \bar{a}^{\prime}{ }^{9}$. As God's oneness clothes him (baqā'), his self-identity is annihilated and what remains is no longer al-Bisțāmī. It is interesting to note that at least in this formulation, even though al-Bisțāmī exists only through the inflowing of God, he is nonetheless not identical with God. Although his most famous utterance, "Subhānī! Ma a'zam šanī" (I am exalted! Great is my glory) is used - ordinarily in the third person - in reference to God, Massignon identifies this with the attributes, not essence of $\operatorname{God}^{10}$. Massignon also notes another saying - "...than God said praising me, the entire world is in slavery to me, except you" - as implying duality, and the inability to attain absolute $\operatorname{tawhid}^{11}$.

'Alī al-Hujwīrī (d. 1072), in famously attempting to classify the fană' traditions, characterizes al-Bisțāmī's teaching as that of rapture (galaba) and intoxication $(s u k r)^{12}$. He juxtaposed it with the tradition he associated with Abū' I-Qāsim al-Junayd (d. 910) - that of sobriety (șaḥw $)^{13}$.To understand al-Junayd's approach, it is helpful to understand his approach toward tawhïd, namely

\footnotetext{
${ }^{4}$ Surā Al-Rahmān 55:26-27. Cf. Surā Al-Qașaș 28:88.

${ }^{5}$ Al-Buhārī 81:38; William Graham, Divine Word and Prophetic Word in Early Islam, The Hague, Walter de Gruyter, 1977, p. 173.

${ }^{6}$ Javad Nūrbakhsh, Traditions of the Prophet, New York, Khanigahi, 1981, p. 52.

${ }^{7}$ Andrew Wilcox, "The Dual Mystical Concepts of Fanā' and Baqā' in Early Sufism", British Journal of Middle Eastern Studies 38 (January 2011), p. 97.

${ }^{8}$ Abū Nașr al-Sarraj, Kitāb al-luma' fi-l tașawwuf, ed. Renald A. Nicholson, London, E.J Gibb Memorial, 1914, p. 102; Micheal Sells, "The Infinity of Desire", in Crossing Boundaries, ed. William G. Barnard and Jeffrey J. Kripal, New York, Seven Bridges, 2002, p. 184-229.

${ }^{9}$ Or more precisely fanā' bi'l-tawhīd: annihilation through (or awareness of) unity.

${ }^{10}$ Kitāb al-Iuma' ..., p. 104. Cf. 'Ațțār of Nishapur, Tazkirat al-Auliyā ed. Arthur J. Arberry, London, Penguin, 1990; Louis Massignon, Essay on the Origins of the Technical Language of Islamic Mysticism, transl. Benjamin Clark, Notre Dame, Notre Dame Press, 1997, p. 189; Muḥammad Abdu-r-Rabb, "Abū Yazīd al-Bisțāmī ", PhD Diss., McGill University, 1970.

${ }^{11}$ Louis Massignon, Essay on the Origins..., p. 185-186. Tawhid may be defined simply as the concept of unindividuated oneness at the core of Islamic monotheism.

${ }_{12}$ Carl Ernst, Words of Ecstasy in Sufism, Albany, SUNY Press, 1985, p. 49-50. Cf. 'Alī al-Hujwīrī, Kashf alMahjūb, ed. Reynold A. Nicholson, London, E.J.W Gibb Memorial Trust, 1936.

${ }^{13}$ Crediting a synthesis of his teachers Saqatī and Muhāsibī. See Terry Graham, "Junayd: The master who made Sufism conventionally acceptable" Sufi, 67 (Autumn 2005), p.35-43.
} 
that unification "is the separation of the eternal from that which was originated in time"14. The paradox of unification being achieved by separation implies that the eternal or "the Real" (al-haqq) must be separated from all that is created and ultimately unreal. Al-Junayd describes a three-stage process of the seeker of unification (muwahhid) ${ }^{15}$. The first comprises "the obliteration of attributes... in one's motives when carrying out religious duties". Here the use of fana' clearly portrays a process of the purgation of desire and not a metaphysical state ${ }^{16}$. The second stage is, "the obliteration of one's pursuit after pleasure in obedience of God's requests..." ${ }^{17}$. The third stage is "the obliteration of the consciousness of having attained the vision of God". At this stage, one is obliterated and has eternal life with God, existing only in the existence of God, and though physicality continues, individuality departs ${ }^{18}$. This third $f a n \bar{a}^{\prime}$ can be said to be both the purgation of the final attribute of man's self as well as the onset of the highest mystical state of $f a n \bar{a}^{\prime}$-al-fan $\bar{a}^{\prime}$ (the passing away of awareness of annihilation) ${ }^{19}$.

It is important here to clarify the interdependent nature of the states of $f a n \bar{a}^{\prime}$ and $b a q \bar{a}^{\prime}$ in al-Junayd's thought. While fanā' presents as the total loss of self in contemplation of God and baq $\bar{a}^{\prime}$ as the self overwhelmed by the influx of the attributes of God, this should not be misinterpreted for the idea of incarnation (hülül). Al-Junayd's words demonstrate the nature of this simultaneous interdependence: "He has fan $\bar{a}^{\prime}$ and this too is obliterated because he persists in baq $\bar{a}^{\prime}$ only through complete obliteration $\left(f a n \bar{a}^{\prime}\right)^{\prime 20}$. Al-Junayd also articulated key limitations that perhaps define this doctrine of sobriety (șahw $)^{21}$. In clarifying the immanent yet still transcendent nature of the Divine, he explains that "He causes his desire to flow over him as he wills through his transcendent attribute which he does not share"22. This leads to the state of balā, which al-Junayd characterizes as the return of the self-aware condition ${ }^{23}$.

Wilcox corroborated this theory of sobriety with al-Junayd's condemnation of his younger though contemporaneous interlocutor - Manșūr al-Hallāj (d. 922)24. Following in the footsteps of alBisțāmī, al-Ḥallāj has arguably become the foremost mythical icon of what has been termed the doctrine of intoxication $(s u k r)^{25}$. Massignon articulates the position of al-Hallāj as a nuanced one, emphasizing al-Ḥallāj's rejection of both intoxication and sobriety in favor of the annihilation of

\footnotetext{
${ }^{14}$ Kashf al-Mahjūb, p. 281.

${ }^{15}$ Ali Hassan Abdel-Kader, The Life, Personality and Writings of Al-Junayd, London, Luzac, 1962, p. 81.

${ }^{16}$ Annemarie Schimmel, Mystical Dimensions in Islam, Chapel Hill, University of North Carolina Press, 1975, p. 58.

${ }^{17}$ Andrew Wilcox, "The Dual Mystical...", p. 105. Wilcox notes that in this second stage of fanā', the mystic may or may not enter into the ecstatic state of fan $\bar{a}^{\prime}$. In any case, the mystic would still retain his awareness of the vision of God.

${ }^{18}$ Ali Hassan Abdel-Kader, The Life, Personality..., p. 81.

${ }^{19}$ Note the potential for confusion, fanā' alone can refer to many different states of being.

${ }^{20}$ Ali Hassan Abdel-Kader, The Life, Personality..., p. 89.

${ }^{21}$ Ali Hassan Abdel-Kader, The Life, Personality..., p. 89: "Even so, in this divine state, it is not possible for him to approach ultimate reality which now possesses him...".

${ }^{22}$ Cf. David L. Martin, Al Fanā' and Al-Baqā' in the Work of Al-Junayd Al-Baghdādī, PhD Diss., University of California, Los Angeles, 1984.

${ }^{23}$ Balā can be seen as both an affliction and the affirmation of servanthood given by God in the primordial covenant (mïthāq). Al-Junayd may be implying an implicit affliction as a result of mans agreed upon role. This role necessitates his return to the community and absolute fealty to the exoteric law.

${ }^{24}$ Andrew Wilcox, "The Dual Mystical...", p. 108.

${ }^{25}$ Andrew Wilcox, "The Dual Mystical...", p. 110. Cf. Manșūr al-Ḥallāj, Akbar al-Ḥallāj, ed. Louis Massignon and Paul Kraus, Paris, Larose, 1936.
} 
separation (tafrid) ${ }^{26}$. Explaining al-Hallāj 's theory (isqāt al-wasă'it), as the elimination of anything that separates the worshipper from God, Massignon highlights the transitory nature of the mystical states themselves ${ }^{27}$. Central to this theory is the role of the heart's love as the organ of mystical perception. While notions of love in Islam had been heretofore synonymous with obedience and though ideas of reciprocal love had been earlier articulated, it was al-Hallāj who raised them to primacy $^{28}$. The mystical love of God when fully developed thus becomes a selfless devotion to the will of the Beloved, for the sake of God through surrendering unto God. In this vein, al-Hallāj 's famous utterance of "'Anā al-Haqq" (I am the Truth) may be better rendered as "My 'I' is God", my present "I" is no longer me and "I" am simply a metaphor of God conveyed to man ${ }^{29}$. In this sense, al-Hallāj urges the mystic to go beyond the understanding of the transcendent tawhīd, annihilating all separation towards an immanent union of love ${ }^{30}$.

Following al-Hallāj, the language of explicit union or abnegation becomes less explicit and couched in poetry or allegory. Abū Ḥāmid al-Gazālī (d. 1111) is credited with synthesizing an ethos more acceptable to orthodoxy, yet his synthesis and true position on union and abnegation of the self is somewhat unclear" ${ }^{31}$. On the one hand he seems to glorify the purification and "fusion of the heart with God's name" that is completed by the "total annihilation of the self in God"32. On the other hand, al-Gazāli calls the mystical nearness to God "which for some can be a virtual incarnation (hū $/ \bar{u} l)$, total union (ittiḥād) or fusion (al-wușūl) with God", "not true" ${ }^{133}$. Enigmatically, he also instructs a person in such a state to say nothing but "Whatever has happened, I shall not speak of it..." ${ }^{34}$. Perhaps we can say that what encapsulates al-Gazāli 's thought on the matter is his qualification of annihilation as essentially being a confession of unity or an extinction in unity ${ }^{35}$. This meant the recognition that God was the sole being or sole light in the universe ${ }^{36}$. In this way he distinguishes between actually identifying (ittihād) or being embodied (hū lül) by God in the literal sense while allowing for ambiguous language and interpretation ${ }^{37}$. Similarly, further synthesis arises later in the thought of Ibn Arabi (d. 1240), who conceptualized union as the concept of the unity of all being (wahdat-al-wujūd) ${ }^{38}$. All reality presents as a manifestation of the preexistent eternal

\footnotetext{
${ }^{26}$ Louis Massignon, The Passion of Al-Hallāj, transl. Herbert Mason, Princeton, Princeton University Press, 1982, p. 274.

${ }^{27}$ Herbert Mason, "Hallaj and the Baghdad school of Sufism", in Heritage of Sufism, Vol. 1: Classical Persian Sufism from its Origins to Rumi (700-1300), ed. Leonard Lewisohn, Oxford, One World, 1999, p. 72.

${ }^{28}$ By Al-Basri, Al-Adawiyya, et al. Cf. Margaret Smith, Rabia the Mystic and her Fellow-saints in Islam, Lahore, Hijra, 1983.

${ }^{29}$ Carl Ernst, Words of Ecstasy..., p. $45 \mathrm{ff}$.

${ }^{30}$ Carl Ernst, Words of Ecstasy..., p. $45 \mathrm{ff}$.

${ }^{31}$ Kamarudin Salleh, "An examination on the nature of al-Ghazali's sufism", International Journal of Islamic Studies 17 (1996), p. 47-63.

${ }^{32}$ Abū Ḥāmid al-Gazālī, Al-Munqidh Min al-Dalal, transl. Muhammad Abūlaylah, Washington DC, Council for Research in Values and Philosophy, 2001, p. 56.

${ }^{33}$ Abū Ḥāmid al-Gazālī, Al-Maqsad al-Asna, transl. Robert C. Stade, PhD Diss., University of Edinburgh, 1967, p. 283; Al-Munqidh..., p. 57.

${ }^{34}$ Abū Ḥāmid al-Gazālī, Mishkat al-Anwar, ed. William H. Gairdner, London, Royal Asiatic Society, 1924, p. 7879. Cf. Al-Munqidh....

${ }^{35}$ Majid Fakhry, A Short Introduction to Islamic Philosophy, Theology and Mysticism, Oxford, One World, 1998, p. 78.

${ }^{36}$ Mishkat al-Anwar, p. 76-77; Surā al-Fatiha 1:1.

${ }^{37}$ Majid Fakhry, A Short Introduction..., p. 77. Note that I am using the terms itthad and hullul in the same sense that al-Gazāli seems to be using them.

${ }^{38}$ Mircea Eliade, A History of Religious Ideas, Chicago, University of Chicago Press, 1978, p. 139.
} 
"One" 39 . As such, the goal of abnegation is not the intimate loving relationship of the soul with the beloved but rather the discovery that there is no such thing as individuation at all $^{40}$. Love is superseded by a form of gnosis ( $m a^{\prime} r i f a$ ) because once the soul returns to the One, there is simply no longer any differentiation of the two. With the synthesis of al-Gazālī, the language of abnegation appeared to qualify the dialogical terminology ${ }^{41}$. Ibn Arabi (though with objection) developed it almost totally to the dialectic, integrating it into a discourse of mystical philosophy with profound effect towards systemization and the rise of the devotional orders (tariqas) ${ }^{42}$.

Turning to Judaism, we find the notion of deveikut - loosely translated as "cleaving" and arising out of the Hebrew root d-b-q - as an explicit biblical imperative ${ }^{43}$. Most resonant for our purposes are the verses in Deuteronomy "You must revere the Lord your God; only him shall you worship, to him shall you cleave..." and "While you who cleaved to the Lord your God, are all alive today"44. The precise meaning of this cleaving, however, is unclear. In their biblical context, the injunctions appear to be part of a covenantal obligation between God and the children of Israel ${ }^{45}$. Indeed, early commentaries view these injunctions as a demand for special devotion during the performance of religious obligations, loyalty to God and the avoidance of idolatry, not as referring to personal spiritual motivations of mystical communion ${ }^{46}$. The Talmud itself questions such concepts: "How is it possible to cling to the divine presence... for the Lord is a devouring fire?"47. Interpreting the second aforementioned verse, the Talmud suggests that by marrying one's daughter to a scholar or otherwise benefiting him, it is as if he had cleaved to the divine presence, suggesting a certain reticence toward the possibility of an imminent relationship of union ${ }^{48}$. Later, in a discussion of idolatry, The Talmud contrasts those attached to idolatry like a "cover sealed unto a vessel" with the people who cling to God like "two dates that cling to each other"49. It has been suggested that this too connotes a certain holding back from the mystical uses of this term ${ }^{50}$. Later in the subsequent discussion, however, the Talmud cites an oral tradition (Baraita) alluding to a mystical understanding, contrasting those who worship idols with those children of Israel who cling to God - "literally" (mamash) ${ }^{51}$. Traces of various forms of union can be found in the vast and

\footnotetext{
39 Ibn 'Arabī, Fusūs al-Hikam, transl. Ralph Austin, New York, Paulist Press, 1980, p. 34-36, 46. Cf. Surā alBaqara 2:115.

${ }^{40}$ Steven Katz, Comparative Mysticism, New York, Oxford University Press, 2013, p. 253.

${ }^{41}$ Margaret Sells, "Bewildered Tongue" in Mystical Union in Judaism, Christianity, and Islam, ed. Moshe Idel and Bernard McGinn, New York, Continuum Publishing Company, 1999, p. 116.

${ }^{42}$ Margaret Sells, "Bewildered Tongue", p. 116; Alexander D. Knysh, Islamic Mysticism, Boston, Leiden, 2000, 167; Majid Fakhry, A Short Introduction..., p. 82. The concepts of emanation and fana $\bar{a}^{\prime}$-al-shaikh are beyond the scope of this essay.

${ }^{43}$ Johannes G. Botterweck and Helmer Ringgren, Theological Dictionary of the Old Testament, Grand Rapids, Mich., Eerdmans, 2003, p. 79-85. Note the etymological similarity to baqiya.

${ }^{44}$ Deut. 10:20 and 4:4 respectively. Cf. Gen. 2:24, Deut. 30:19-20 and 11:22 - "ul'davka bo".

${ }^{45}$ Moshe Weinfeld, Deuteronomy and the Deuteronomic School, Oxford, Clarendon, 1972, p. 83-84.

${ }^{46}$ Sifre (Deut. 11:22).

${ }^{47}$ BT Ketubot 111B. Cf. Deut. 4:24 and Dan. 7:9.

${ }^{48}$ See Joshua Abelson, Immanence of God in Rabbinical Literature, London, Macmillan, 1912, for an alternative understanding of immanence.

${ }^{49}$ BT Sanhedrin 64A, Rashi. Maharsha ad. loc. understood this as a pejorative with respect to the Jewish people, as two dates are easily separated. By contrast, in the interpretation of the Baraita, the Jews (or at least the ones who cling) are being praised.

${ }^{50}$ Abraham J. Heschel, Theology of Ancient Judaism, London, Soncino, 1962, p. 38. Cf. Pesikta Rabbati 86B ed. Meir Friedman, Vienna, Kaiser, 1880; Moshe Idel, Kabbalah: New Perspectives, New Haven, Yale University Press, 1990.

${ }^{51}$ BT Sanhedrin 64A.
} 
exhaustive varieties of ancient Jewish mysticism ${ }^{52}$. However, for the purposes of this paper and following arguments put forth by Afterman, we shall specify the "henosis" and "embodiment" forms of individual union as most consonant with the ideas of self-abnegation ${ }^{53}$.

Beginning in the medieval period, we find an articulation of the religious ideal of deveikut as spiritual or mental attachment and even union with $\mathrm{God}^{54}$. With the exception of Philo, this type of union had been absent in the Jewish tradition ${ }^{55}$. Altmann and Stern claim the figure of Isaac Israeli (d. 955) as the first medieval Jewish author to articulate a Jewish path to mystical union ${ }^{56}$. Incorporating the ideas of spiritual return and mystical union into a systematic exposition of Rabbinic Judaism, Israeli called the three stages of ascension (purification, illumination and union) the inner meaning of Judaism and its path ${ }^{57}$. Afterman argues that this synthesis paved the way for much of the employment of the terminology of deveikut, both philosophical and mystical (in the medieval period $)^{58}$. It is important to recognize here that Israeli seems to portray two versions of the final stage, describing both as deveikut. In several of his discussions he describes a mystical union with the divine light while in others milder forms of attachment or conjunction are described. Similarly, Solomon Ibn Gabirol (d. 1058) clearly articulates a union with the divine intellect (nous) and describes a mystical union with the "One", but leaves the notion of absolute mystical union with God somewhat ambiguous. It is also worthwhile to note in passing the works of Bahya Ibn Pakudah (d. $11^{\text {th }}$ cent.). Although he falls short in describing full union as such, he describes the overwhelming love of God as deveikut in the form of communion ${ }^{59}$.

Abraham Ibn Ezra (d. 1167) also articulates this union with the divine nous and ties it specifically to the injunction to cleave to God. In his thought, the language of union crucially describes a process in which the human soul loses its concrete and particular existence, and becomes one with the divine nous, described as the universal "All" (hakol) ${ }^{60}$. This "All" stands for God who is described as the origin of everything or, alternatively, as the origin of the universal soul ${ }^{61}$. This transformation is possible because the human soul originates from the universal and after separation from the body returns to the universal. Crucially, in this phase of religious human transformation, solely the intellectual part of the human soul retrieves its primordial noetic features and actually "unites" or reunites with the "All"62. Ibn Ezra's thought had a major influence over

\footnotetext{
${ }^{52}$ For a fuller purview, see Gershom Scholem, Major Trends in Jewish Mysticism, London, Thames and Hudson, 1955; Elliot Wolfson, Through a Speculum That Shines, Princeton, Princeton University Press, 1997.

${ }^{53}$ Adam Afterman, And They Shall Be One Flesh, Leiden, Brill, 2016, p. 95, 98, 238.

${ }^{54}$ See introductory footnote. The extent of influence from Aristotelian, Neoplatonic and Sufi thought and sources is beyond the scope of this essay.

${ }^{55}$ For some fascinating confluences in the works attributed to Philo, R' Akiva, Plotinus, Numenius and Lamblichus, et al., see Menahem Stern, Greek and Latin Authors on Jews and Judaism, Jerusalem, Israel Academy of Sciences and Humanities, 1992; Cf. Joseph Dan and Frank Talmage, Studies in Jewish Mysticism, Cambridge, MA., Association for Jewish Studies, 1982.

${ }^{56}$ Alexander Altmann and Samuel M. Stern, Isaac Israeli, Chicago, University of Chicago Press, 2009, p. 185217.

${ }^{57}$ Adam Afterman, And They Shall..., p. 79-80. Note the correlation between the Greek henosis, the Arabic ittihād, and the Hebrew yachud and davek.

${ }^{58}$ Adam Afterman, And They Shall..., p. 79-80.

${ }^{59}$ Bahya Ibn Pakudah, Chovot HaLevavot, ed. Pinhas Yehudah Lieberman, Jerusalem, 1968, p. 63, 259-261. Cf. Diana Lobel, A Sufi-Jewish Dialogue, Philadelphia, University of Pennsylvania Press, 2013.

${ }^{60}$ Abraham Ibn Ezra, Perushé HaTorah, ed. Asher Vaizer, Jerusalem, Mossad Harav Kook, 1976, p. 20, 303-306.

${ }^{61}$ Abraham Ibn Ezra, Perushé HaTorah, p. 341. Cf. Isa. 44:24.

${ }^{62}$ Abraham Ibn Ezra, Y'sod Mora V'sod Hatorah, ed. Joseph Cohen and Uriel Simon, Ramat-Gan, Bar-Ilan University Press, 2002, p. 55, 192-194, 200.
} 
succeeding developments in both Jewish philosophy as well as later in Kabbalistic and Hasidic thought $^{63}$.

It is also important to note the contribution of Judah Halevi (d. 1141) which added a significant component to later articulations of union. Throughout his major work, Halevi discusses two forms of cleaving using similar terminology, articulating both a human striving for mystical connection and a form of embodiment or cleaving initiated from above ${ }^{64}$. As Israeli developed the henosis form of union, Halevi developed the embodied union. Though it has been argued that Halevi intended a milder form of collective cleaving by and within the Jewish people rather than true individual union, it is hard to overstate this idea's importance ${ }^{65}$. The wide range of the expressions of embodiment include states that have clear ontological ramifications, later picked up by mystics such as Nachmanides (d. 1270) and Abraham Abulafia (d. 1290's) ${ }^{66}$.

Focusing strictly on the language of union in the works of Maimonides (d. 1204), we find two key aspects which he identifies as cleaving/union: firstly, the ontic cleaving to the active intellect, and secondly a postmortem union with a metaphysical noetic realm leading to a permanent union with God ${ }^{67}$. Two main followers in this matter were Nachmanides and Abraham Abulafia $^{68}$. Whilst Nachmanides understood the Maimonidean eschatological union as a rare ideal of almost perfection, Abulafia took this as a starting point to a radically different mystical path. Following in Maimonides footsteps he defined the first step as establishing contact with the noetic efflux descending from supernal realms. Abulafia than described a process designed to free human thought entirely toward disintegration and a unitive experience with the divine itself ${ }^{69}$. The one willing to put in "hard, strong and mighty exercises" will unite with the active intellect, his "personal faculty will turn prophetic and universal, similar to the essence of his cause and he and He will become one entity"70. As Idel has noted, in using powerful phrases such as "I am he and He is I" and "I, I", Abulafia fused the idea of universalization and union with the active intellect towards a radical discourse of becoming one with $\mathrm{God}^{71}$. Isaac of Acre (d. $14^{\text {th }}$ cent.) also developed themes along these lines, using examples of unitive and annihilative imagery that some call extreme. Allowing for one to reach a state of eschatological union while still alive, he cautions against the risk of premature

\footnotetext{
63 Moshe Idel, "Universalization and Integration: Two Conceptions of Mystical Union in Jewish Mysticism", in Mystical Union in Judaism, Christianity and Islam, ed. Moshe Idel and Bernard McGinn, New York, Continuum Publishing Company, 1999, p. 28-30. For purposes of brevity, we will not digress into his many interconnected ideas concerning eschatology, miracles, angels or the divine kiss. Cf. Abraham Ibn Ezra, Perushé HaTorah, Psalms 1:1.

64 Judah HaLevi, Sefer HaKuzari, ed. Even Shmuel, Tel Aviv, Dvir, 1972, p. 97, 142.

${ }^{65}$ Adam Afterman, And They Shall..., p. 93, 98; Diana Lobel, Between Mysticism and Philosophy, Albany, SUNY Press, 2000, p. 147-156.

${ }^{66}$ Sefer HaKuzari, p. 171-174; Cf. p. 14-15, 154-165, 258.

${ }^{67}$ Simplified considerably. See Isadore Twersky, Studies in Maimonides, Cambridge, MA., Harvard University Press, 1992, p. 159-207.

68 Moshe ben Nachman (Nachmanides), Shaar Hagemul in Kitvei Ramban, ed. Chaim Dov Chavel, Jerusalem, Mossad Harav Kook, 1963, p. 264. Cf. Moshe ben Nachman (Nachmanides) Ramban al HaTorah (Lev.18.4), ed. Pinhas Yehudah Lieberman, Jerusalem, Schreiber Books, 1985.

${ }^{69}$ Elliot Wolfson, "Kenotic Overflow and Temporal Transcendence: Angelic Embodiment and the Alterity of Time in Abraham Abulafia", Kabbalah 18 (2008), p. 133-190.

70 Moshe Idel, Kabbalah: New Perspectives, p. 62-65. Cf. Abraham Abulafia, Sitrei Torah al Moreh Nevuchim, transl. Yaron Ever Hadani, Providence, Providence University, 2009; Bodleian Library, Oxford University, MS Oxford 1649, fl. 206A.

71 Moshe Idel, Studies in Ecstatic Kabbalah, Albany, SUNY Press, 2014, p. 1, 12. See Elliot Wolfson, "Kenotic Overflow..." for other examples.
} 
annihilation ${ }^{72}$. He explained that Moses sought his own death in order that his soul should obliterate the barriers between itself and the divine light. This necessitated God's refusal considering Moses' importance at that juncture ${ }^{73}$. The same motif arises exegetically on the verse in Genesis in which man's cleaving to his wife as one flesh becomes metaphor for the mystic, allowing his soul to ascend and cleave to the divine which cleaves back, ultimately swallowing the soul ${ }^{74}$.

The language of mystical union and embodiment in the Zohar has been the subject of much scholarly endeavor. It is safe to state generally, that while the theosophical aspects of unity and union play crucial roles, the tension between transcendent and immanent conceptions of God does not allow for the full flowering of mystical union or annihilation ${ }^{75}$. Indeed, it may not even be an end in itself ${ }^{76}$. The language of union, embodiment and annihilation picks up steam towards the $16^{\text {th }}$ century in the works of Hayyim Vital (d. 1620) who emphasized Torah learning as a means in which to "link one's soul and bind it... and make it cleave to its supernal source"77. Similarly, quoting extensively from Isaac of Acre, Elijah de Vidas (d. 1592) explained that "Souls are hewn from him, and he and they are two parts... and when part of the lower soul unites with him, the two parts become united and one"78. De Vidas' work had a direct influence on early Hasidism in which mystical union, embodiment and indeed nullification became a fundamental language of Hasidic mysticism ${ }^{79}$. Indeed, the Great Maggid of Hasidism, Dov Ber of Mezeritch (d. 1772), echoed de Vidas in his exposition on the separation of man (A-DaM). Discussing God's contraction of the divine self, he expounds that humans (DaM) must separate from this world to such an extent that they will ascend through all the worlds and unite with God $(A)$ until their very existence is nullified (or annihilated). Each alone is incomplete and only half a form, yet together they are one complete form ${ }^{80}$. Among many of his disciples, the theme of union to the point of annihilation became widespread ${ }^{81}$. Menachem Mendel of Vitebsk (d. 1788) discussed mystics annihilating themselves by becoming comprised in the sources of their influx, calling this state a complete deveikut (hadeveikut hagamur) ${ }^{82}$. His younger contemporary, Shneur Zalman of Liady (d. 1812) - in an overarching syncretic synthesis - developed this idea further as a state of interpenetration (hitkallelut) between upper and lower unities that must be united (yichud ill'aha and yichud tata'ah), stating that the soul is annihilated in the way of a wick in flames ${ }^{83}$. The more the wick is consumed by fire, the more the flame of the fire prevails in it and enters the innermost part of the wick. In his expositions - while he alternates somewhat in terminology - utter nullification of the substance of self (bitul ha'ayin) is

\footnotetext{
72 It would seem though, that he viewed it as the final positive stage of the mystical path.

73 Isaac of Acre, Sefer Otzar Hayim (Exod. 33:18); Adam Afterman, And They Shall..., p. 244, citing Moscow, Russian State Library [Lenin Library], MS Günzburg 775, fl. 14A.

${ }^{74}$ Gen. 2:24. See Num. 4:20, Lev. 10:1-7 for examples of the consequences.

75 Adam Afterman, And They Shall..., p. 137; Moshe Idel, "Universalization and Integration...", p. 54.

${ }^{76}$ Cf. Hartley Lachter, Paradox and Mystical Union in the Zohar, PhD Diss., New York University, 2004.

77 Steven Katz, Comparative Mysticism, p. 108. Cf. Moshe Idel, Kabbalah: New Perspectives, p. 57, 300, note 155, where other parallels in Lurianic texts are cited.

${ }^{78}$ Elijah de Vidas, Reishit Chochma, ed. Chaim Yosef Waldman, Jerusalem, Ohr haMussar, 1984, p. 385 ff.

${ }^{79}$ Adam Afterman, And They Shall..., p. 232.

${ }^{80}$ Dov Ber of Mezeritch, Maggid Devarav L'Yaakov, ed. Rivka Schatz-Uffenheimer, Jerusalem, Magnes Press, 1976 , p. 24, 38-40, simplified and redacted by this author.

${ }^{81}$ See the nuances in the Hasidic works of Amdur, Berditchov, Breslov, Satanov, Zlotshiv et al. that are beyond the limited scope of this paper.

${ }^{82}$ Menachem Mendel of Vitebsk, Likkutei Amarim (Vitebsk) in Seforim Kedoshim M'Talmidei Baal Shem Tov Hakadosh, Brooklyn, NY., Beit Hillel, 1984, p. 15 ff. (reprint of edition, Lemberg, Druck von St. Kubler, 1911).

${ }^{83}$ Shneur Zalman of Liady, Likkutei Amarim (Tanya), Brooklyn, NY., Kehot Publication Society, 1981, p. 77-79 (Chap. 19); Dov Ber of Lubavitch, Ner Mitzvah v'Torah Or, Brooklyn, NY., Kehot Publication Society, 1986. Cf. Aharon Halevi of Staroshleye, Shaar HaYichud v'Emunah, Jerusalem, Makor, 1969; Sefer HaZohar 1:18b.
} 
but a step (albeit a high one) to the clear overarching goal of the utter nullification of all existence other than God (bitul ha'metziut) ${ }^{84}$.

Wilcox argued that Islam is unique in reconciling what he terms the notion of "Divine Immanence" with the inviolable transcendence of God. By contrast, he maintains that Judaism ultimately comes down on the side of transcendence. Echoing Scholem, he claims that the Jewish mystic invariably retains the sense of distance between the Creator and the created ${ }^{85}$. Indeed, one of the most widely accepted ideas in the scholarship of Jewish mysticism is the supposed reticence of Jewish mystics to express their experiences in a way that could be understood as total union with God. Caird described this in a clear way: "The Jew has always defended against the extremes of mysticism by his strong sense of the separate between God and man"86. As has been amply demonstrated above, the figure of Abulafia in particular and a nuanced exposition of the Hasidic movement puts this notion of a strictly transcendent Judaism to rest. Further, this paper directly opposes such a view. We contend here that not only do the two traditions carry both the ideas of the transcendent and the immanent, but that they do so in remarkably similar ways. Particularly in our area of abnegation, four distinct developments have paralleled each other. Firstly, in both traditions, the notion of an absolute transcendental God is explicit and foundational. The absolute unity of God is not simply a theological abstract, but recited as credo multiple times in the daily liturgy of both traditions ${ }^{87}$. Remarkably though, in both arose the notion of not only cleaving to a transcendent unity, but ideas of conjunction, union and even annihilation. Secondly, as we have seen repeatedly above, was the deep sensitivity towards the sanctity of the transcendental character of God. One constantly feels the tension arising from expressions that appear to lead down the immanent path only to reach almost a token caveat - "Of course we don't mean it in that way". This can be seen explicitly in many of the works of al-Gazāli and particularly Ibn Ezra and Nachmanides. Thirdly, within both of these traditions and their extremely similar limitations arose figures destined to shatter this tension and overthrow the status quo. Figures like Abulafia and alHallāj occupy eerily similar spaces within their respective traditions. Idel notes that there was less opposition to Abulafia than in the Muslim world toward al-Hallāj, citing the lack of a call for the death penalty ${ }^{88}$. This may be disingenuous. Abulafia was constantly hounded by his detractors, forced into a peripatetic existence and eventually forcibly exiled to a remote island. More significantly, Shlomo ben Aderet (d. 1310) - a leading Talmudist of his day - referred to him as a disgusting evildoer under a maxim derived from the biblical annihilation of Sodom ${ }^{89}$. Later students led with a charge of idol worship (Avoda Zara); a charge that upon conviction, certainly leaves one liable to a death sentence ${ }^{90}$. Due to the nature of Jewish exile and lack of authority, such a sentence could have hardly been carried out, but this does not diminish the point.

Lastly, accusations of heresy notwithstanding, in both traditions the "extreme" formulations eventually found their way back into the mainstream traditions. Whether in the case of

\footnotetext{
${ }^{84}$ Highly simplified and truncated by this author. Cf. Ner Mitzvah v'Torah Or; Kuntret Hitpallelut, transl. Louis Jacobs, Chappaqua, Vallentine Mitchell, 1963. Note that Mesirat Nefesh may be presented as a euphemism for Bitul b'Metziut.

${ }^{85}$ Andrew Wilcox, "The Dual Mystical...", p. 95-96.

${ }^{86}$ Moshe Idel, Kabbalah: New Perspectives, p. 59. Cf. Edward Caird and Colin Tyler, Collected Works of Edward Caird, Bristol, Thoemmes, 1999.

${ }^{87}$ The "Shema" and the "Shahada", respectively.

${ }^{88}$ Moshe Idel, "Comments", in Mystical Union in Judaism, Christianity and Islam, ed. Moshe Idel and Bernard McGinn, New York, Continuum Publishing Company, 1999, p. 159.

${ }^{89}$ Solomon ben Aderet, Shealot u'Teshuvot HaRashba 1:548, Bnei Brak, Sifriati, 1958; BT Yoma 38B.

${ }^{90}$ Aryeh Kaplan, Meditation and Kabbalah, Boston, Weiser, 1982, p. 58. Cf. BT Sanhedrin 63B.
} 
reconciliation and synthesis of al-Gazālī and Ibn 'Arabī or the recombination's of the Hasidic movement, great attempts were made to reconcile seemingly irreconcilable ideas within the confines of pre-existing orthodoxies. This required immense creativity along with a dogged determination to frame deeply appealing ideas within the confines of a received tradition. In our context, that of abnegation, the questions become striking. What is it about the desire to cleave, unify or abnegate that animates the human being so? Katz, in arguing for the contextualist approach to mysticism, maintains that mystics of their respective traditions are so suffused in their own ontologies so as to shape their ideas and experiences entirely ${ }^{91}$. Simply speaking this may be true. Islamic mystics did indeed couch their ideas within Quranic sources and Jewish mystics did the same with the Torah. Structurally however, as we have shown, the remarkably similar trajectories arising from deep within both distinct traditions appear impossible to ignore.

${ }^{91}$ Steven T. Katz, Mysticism and Religious Traditions, Oxford, Oxford University Press, 2011, p. 3-5; Steven T. Katz, "Language, Epistemology and Mysticism", in Mysticism and Philosophical Analysis, ed. Steven T. Katz, New York, Oxford University Press, 1978, p. 22-74. 